\title{
Konsentrasi Surfaktan dan Minyak di Perairan Depapre, Kabupaten Jayapura, Provinsi Papua
}

\author{
Rosye Hefmi Rechnelty Tanjung ${ }^{1 *}$, Baigo Hamuna ${ }^{2}$, Alianto ${ }^{3}$ \\ ${ }^{I}$ Jurusan Biologi, Fakultas Matematika dan Ilmu Pengetahuan Alam, Universitas Cenderawasih \\ Jl. Kamp Wolker, Kampus Universitas Cenderawasih, Yabansai, Kota Jayapura, Papua, 99351 \\ ${ }^{2}$ Jurusan Ilmu Kelautan dan Perikanan, Fakultas Matematika dan Ilmu Pengetahuan Alam, Universitas Cenderawasih \\ Jl. Kamp Wolker, Kampus Universitas Cenderawasih, Yabansai, Kota Jayapura, Papua, 99351 \\ ${ }^{3}$ Jurusan Perikanan, Fakultas Perikanan dan Ilmu Kelautan, Universitas Papua \\ Jl. GunungSalju, Kampus Universitas Papua, Amban, Manokwari, Papua Barat, 98314 \\ Email:*hefmitanjung@yahoo.co.id
}

\begin{abstract}
Abstrak
Kondisi kualitas air suatu perairan yang baik sangat penting untuk mendukung kehidupan organisme yang hidup di dalamnya. Penentuan status mutu air perlu dilakukan sebagai acuan dalam melakukan pemantauan pencemaran kualitas air. Penelitian ini bertujuan untuk mengkaji status mutu air laut berdasarkan konsentrasi parameter surfaktan dan minyak di perairan Distrik Depapre, Kabupaten Jayapura. Pengambilan sampel air laut dilakukan di lima stasiun penelitian, kemudian hasilnya dibandingkan dengan baku mutu air laut untuk biota laut berdasarkan KEPMEN-LH No. 51 Tahun 2004. Hasil penelitian menunjukkan bahwa konsentrasi surfaktan di perairan Distrik Depapre berkisar antara 0,08-0,22 mg/L, sedangkan konsentrasi kandungan minyak berkisar antara 0,14-0,41 mg/L. Berdasarkan baku mutu air laut, konsentrasi surfaktan dan minyak belum melampaui baku mutu dan masih sesuai untuk biota laut di perairan Depapre, Kabupaten Jayapura. Hasil penelitian ini memberikan informasi bahwa kondisi perairan Depapre belum tercemar oleh limbah surfaktan dan minyak. Namun tidak menutup kemungkinan bahwa konsentrasi tersebut dapat terus meningkat, sehingga perlu upaya lebih lanjut dari pemerintah dan masyarakat untuk meminimalkan jumlah limbah surfaktan dan minyak yang masuk kelingkungan perairan laut.
\end{abstract}

Kata kunci : mutu perairan, surfaktan, minyak, perairan Depapre, Papua

Abstract

Surfactant and Oil Concentration in Jayapura Regency, Papua Province

Good water quality is critical to support the life of organisms. The determination of water quality status was needed as a reference to monitor water pollution. This study aimed to assess the condition of water quality based on the concentration of surfactant and oil parameters in the Depapre waters, Jayapura Regency. Sampling was carried out in five research stations; then the results were compared with water quality standards based on KEPMEN-LH No. 51 Tahun 2004 for marine biotas. The result showed that the concentration of surfactant in Depapre waters was $0.08-0.22 \mathrm{mg} / \mathrm{L}$, while the oil concentration was 0.14$0.41 \mathrm{mg} / \mathrm{L}$. Based on water quality standards, surfactant and oil concentration has not exceeded the quality standards and are suitable for marine biotas in Depapre waters, Jayapura Regency. Results showed the condition of Depapre waters had not been polluted by surfactant and oil waste. However, it does not rule out the possibility that the concentration can increase so that it needs further efforts from the government and the community to minimize the amount of surfactant and oil waste entering the marine environment.

Keywords: water quality, surfactant, oil, Depapre waters, Papua

\section{PENDAHULUAN}

Permasalahan yang sangat dominan bagi wilayah pesisir, pantai dan laut adalah terjadinya pencemaran yang mengakibatkan terjadinya penurunan kualitas dan kuantitas sumberdaya pesisir dan laut. Berdasarkan Peraturan
Pemerintah Republik Indonesia Nomor 19 Tahun 1999 tentang Pengendalian Pencemaran dan/atau Pengrusakan Laut bahwa pencemaran laut adalah masuknya atau dimasukkannya makhluk hidup, zat, energi, dan/atau komponen lain ke dalam lingkungan laut oleh kegiatan manusia sehingga
*Corresponding author

DOI:10.14710/buloma.v8i1.22264 http://ejournal.undip.ac.id/index.php/buloma

Diterima/Received : 04-03-2019

Disetujui/Accepted : 05-04-2019 
kualitasnya turun sampai tingkat tertentu yang menyebabkan lingkungan laut tidak sesuai lagi dengan baku mutu dan/atau fungsinya.

Berbagai jenis bahan pencemar yang sering dilaporkan adalah logam berat, nutrien, surfaktan maupun minyak (hidrokarbon). Di Indonesia, konsentrasi parameter bahan percemar telah diatur dalam Keputusan Menteri Lingkungan Hidup Nomor 51 Tahun 2004, yang apabila konsentrasinya di perairan pesisir dan laut telah melebihi baku mutu yang telah ditentukan, maka dipastikan akan menyebabkan pencemaran dan berdampak negatif bagi organisme atau biota laut yang ada di perairan tersebut. Menurut Gholizadeh et al. (2016) bahwa setiap perubahan dalam ekosistem rentan akibat kegiatan antropogenik dapat membahayakan habitat ikan dan organisme air lainnya. Kualitas air laut yang digunakan untuk biota laut dan aktivitas lain secara ideal harus memenuhi standar, baik secara fisik, kimia, dan biologi. Nilai kualitas perairan laut yang telah melampaui ambang batas maksimum untuk peruntukannya akan digolongkan sebagai perairan tercemar (Tanjung et al., 2019). Berbagai kejadian pencemaran di perairanpesisirdanlauttelah berdampak negatif yang dapat mengancam pengembangan potensi suatu wilayah pesisir (Pramudyanto, 2014). Limbah atau bahan pencemar dapat terakumulasi pada lingkungan perairan, sedimen, dan organisme laut (Rejomon et al., 2008; Ariani et al., 2016).

Pencemaran surfaktan dan minyak (hidrokarbon) sering terjadi di laut baik pada skala besar maupun kecil. Surfaktan dalam produk detergen memiliki sifat sulit terurai yang disebabkan oleh adanya rantai bercabang pada strukturnya (Riza et al., 2015). Surfaktan dalam jumlah tertentu dapat mencemari lingkungan karena dapat menimbulkan banyak busa pada permukaan air, sehingga mengganggu difusi oksigen dari udara ke dalam perairan yang secara tidak langsung dapat mengganggu kehidupan organisme perairan, terutama pada berbagai organ ikan (Taufik, 2006). Begitupun dengan bahan pencemar minyak, berbagai kasus tumpahan minyak akibat dari tenggelam atau bocornya kapal tanker maupun tumpahan dari tambang minyak off shore merupakan sumber utama pencemaran minyak (Perez et al., 2008). Sumber utama pencemaran laut adalah berasal dari tumpahan minyak baik dari proses di kapal, pengeboran lepas pantai maupun akibat kecelakaan kapal. Limbah tumpahan maupun buangan yang mengandung minyak apabila dibuang langsung ke perairan laut, maka akan mengapung menutupi permukaan air laut dan akan mengganggu biota dan mikroorganisme dalam air laut tersebut (Shaheen, 1992).

Wilayah perairan pesisir dan laut Distrik Depapre termasuk dalam wilayah administrasi Kabupaten Jayapura, Provinsi Papua. Dalam perkembangannya, wilayah pesisir tersebut telah mengalami pengembangan untuk berbagai macam kepentingan dan peruntukan, seperti kegiatan pelabuhan, pariwisata bahari, pemukiman dan maritim serta pengembangan budidaya laut dan perikanan. Tingginya aktifitas dan pemanfaatan wilayah pesisir tersebut sebagai bentuk perkembangan pembangunan daerah dikhawatirkan akan memberikan pengaruh pada lingkungan perairan di sekitarnya. Berdasarkan hasil penelitian Hamuna et al. (2018), sebagian perairan Distrik Depapre telah tergolong perairan tercemar (kategori tercemar ringan dan tercemar sedang). Perubahan lingkungan secara perlahan akan memberikan efek secara langsung maupun tidak langsung kepada biota-biota perairan dan manusia sebagai pengkonsumsinya.

Penelitian ini bertujuan untuk mengkaji konsentrasi bahan pencemar surfaktan dan minyak (termasuk lemak) di perairan Distrik Depapre, Kabupaten Jayapura, sebagai langkah awal untuk mengantisipasi terjadinya pencemaran surfaktan dan minyak di lingkungan perairan. Hasil dari penelitian ini diharapkan dapat memberikan informasi dasar dan output bagi pemerintah daerah dan masyarakat umum, khususnya mengenai kualitas air laut (surfaktan dan minyak) sehingga dapat dijadikan sebagai masukan dalam pengelolaan wilayah pesisir Kabupaten Jayapura, Provinsi Papua.

\section{MATERI DAN METODE}

Lokasi pengambilan sampel air laut sebanyak 5 stasiun, sebagaiberikut: 1) Perairan pantai wisata Harlem, 2) Perairan pesisir Kampung Tablasupa (pemukiman penduduk berada di perairan), 3) Perairan Pulau Dua, 4) Perairan lokasi pembangunan pelabuhan Depapre, 5) Perairan Kampung Depapre (pemukiman penduduk berada di daratan) (Gambar 1).

Sampel air laut yang telah diambil kemudian dimasukkan kedalam memasukkan sampel air laut ke dalam botol Niskin dan disimpan dalam coolbox untuk dianalisis di Laboratorium Kesehatan Daerah (Lab KESDA) Kota Jayapura, Provinsi Papua. Metode pengujian konsentrasi surfaktan berdasarkan pada Standard Method 2005, Section 5540-C, sedangkan 
konsentrasi minyak berdasarkan SNI 06-6989.102003.

Pada penelitian ini, penentuan konsentrasi surfakatan ditentukan melalui metode MBAS (Methylene blue active substances). Metode MBAS merupakan metode internasional yang diterapkan oleh the American Public Health Association (APHA), the American Water Works Association (AWWA), dan the Water Environment Federation (WEF). Pada dasarnya, MBAS merupakan suatu substansi yang memindahkan metilen biru, pewarna kationik dari larutan ke dalam cairan pelarut organik yang tidak larut dalam air. Intensitas warna biru yang dihasilkan dalam fase organik adalah dalam ukuran MBAS. Metode MBAS terdiri dari tiga ekstraksi berturut-turut, yaitudari media air asam yang mengandung kelebihan metilen biru menjadi kloroform $\left(\mathrm{CHCl}_{3}\right)$, diikuti oleh pencucian air, dan pengukuran warna biru dalam $\mathrm{CHCl}_{3}$ dengan spektrofotometri pada panjang gelombang 652 nm.

Analisis data hasil pengujian laboratorium dilakukan secara deskriptif, yaitu dengan membandingkan hasil analisis konsentrasi surfaktan dan minyakyang diperoleh dengan baku mutu kualitas air laut berdasarkan Keputusan Menteri Lingkungan Hidup Nomor 51 Tahun 2004 tentang Baku Mutu Air Laut yang dikhususkan untuk menunjang kehidupan biota laut.

\section{HASIL DAN PEMBAHASAN}

\section{Konsentrasi Surfaktan di Perairan Depapre}

Pencemaran surfaktan di perairan terutama detergen dan sabun banyak berasal dari limbah rumah tangga dimana penggunaan bahan ini semakin tinggi (Becker et al., 2008). Hasil analisis konsentrasi surfaktan (detergen) di perairan Distrik Depapre, Kabupaten Jayapura menunjukkan nilai yang masih rendah, yaitu berkisar 0,08-0,22 mg/L MBAS (Gambar 2). Nilai yang diperoleh masih di bawah standar baku maksimum konsentarasi surfaktan untuk biota laut sebagaimana dalam KEPMEN Negara Lingkungan Hidup No. 51 tahun 2004, yaitu sebesar $1 \mathrm{mg} / \mathrm{L}$ MBAS. Nilai tersebut menunjukkan bahwa perairan Distrik Depapre, Kabupaten Jayapura dalam kondisi tidak tercemar oleh limbah surfaktan dan masih aman untuk kehidupan biota laut.

Kondisi masyarakat pesisir Distrik Depapre yang memanfaatkan wilayah pesisir sebagai area pemukiman, misalkan Kampung Tablasupa, Kampung Depapre, dan kampung lainnya di Distrik Depapre yang sebagian besar berhubungan langsung dengan perairan laut merupakan faktor penyebab utama dan memungkinkan untuk bertambahnya konsentrasi limbah surfaktan di perairan laut tersebut. Kebiasaan masyarakat pesisir Distrik Depapre yang membuang sisa air limbah detergen langsung ke laut atau melalui aliran sungai dapat menyebabkan akumulasi bahan pencemar tersebut di perairan laut.

Berdasarkan perbandingan konsentrasi surfaktan pada Gambar 1, terlihat bahwa stasiun 2 memiliki konsentrasi surfaktan di perairan laut lebih tinggi. Tingginya konsentrasi surfaktan di stasiun 2 (Kampung Tablasupa) disebabkan karena lokasi pemukiman masyarakat berada di atas perairan laut, sehingga limbah atau sisa air penggunaan detergen dan sabun mandi yang mengandung surfaktan langsung dibuang ke laut tanpa terserap oleh tanah. Adapun konsentrasi surfaktan yang cukup tinggi di stasiun 1 (Pantai Harlem), selain dari sisa penggunaan sabun mandi

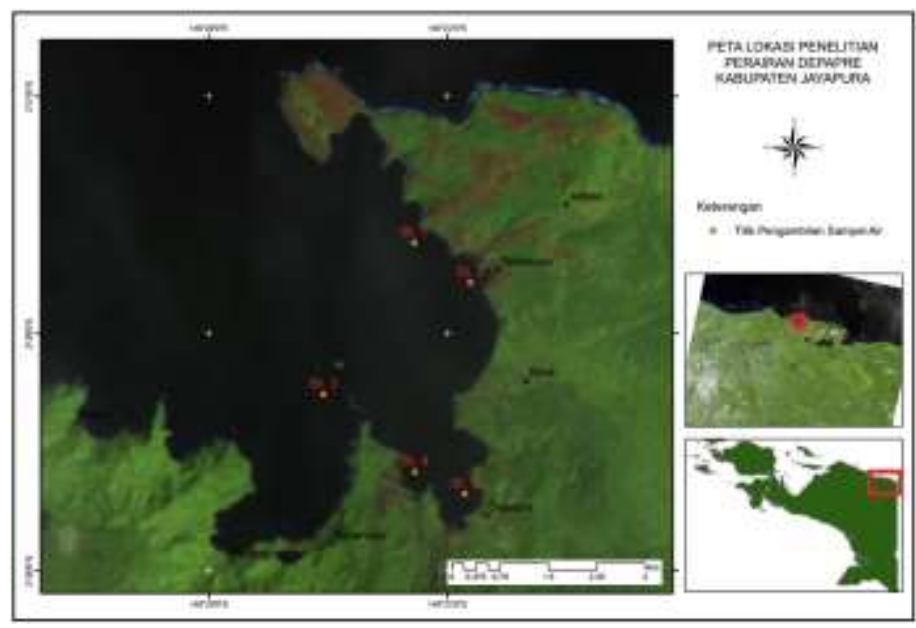

Gambar 1. Peta lokasi pengambilan sampel air laut di perairan Depapre, Kabupaten Jayapura 
dari wisatawan, juga diduga berasal dari Kampung Tablasupa karena lokasi kedua stasiun tersebut cukup berdekatan. Walaupun jumlah penduduk pada stasiun 4 dan 5 lebih padat (ibukota Distrik Depapre), namun lokasi pemukiman masyarakat tidak berada di perairan laut seperti Kampung Tablasupa (Stasiun 1), sehingga limbah sisa detergen dan sabun tidak langsung dibuang ke laut. Konsentrasi surfaktan yang paling rendah pada stasiun 3 (Pulau Dua) karena lokasi tersebut merupakan pulau yangtidak berpenghuni, sehingga limbah surfaktan (detergen dan sabun) yang ada di perairan tersebut berasal dari lokasi lain yang terbawa oleh arus dan gelombang laut.

Masuknya limbah surfaktan melalui pembuangan sisa detergen ke dalam perairan Distrik Depapre umumnya disebabkan karena pengetahuan masyarakat yang mengganggap bahwa detergen bukanlah suatu bahan yang berbahaya dan tidak bersifat toksik, sehingga limbah cairnya dapat dibuang langsung ke laut dan tanpa perlakuan khusus. Selain itu, kurangnya kesadaran masyarakat terhadap kesehatan lingkungan dapat sebagai pemicu percemarnya perairan oleh limbah detergen, akibatnya perairan umum seperti laut dan sungai dianggap sebagai lokasi yang paling ideal sebagai tempat pembuangan akhir limbah domestik rumah tangga. Kondisi ini apabila berlangsung secara terus-menerus dan dalam waktu yang lama tanpa adanya penanggulangan, maka akan menyebabkan terjadinya pencemaran di perairan laut dan secara tidak langsung akan berpengaruh terhadap biota laut.

Menurut Taufik (2006), surfaktan dalam bentuk detergen dapat mengganggu difusi oksigen dari udara ke dalam perairan yang secara tidak langsung dapat mengganggu kehidupan organisme perairan. Selain itu, senyawa fosfor dan nitrogen yang terkandung dalam detergen dapat menyebabkan terjadinya eutrofikasi di perairan. Pencemaran dari buangan detergen di perairan dapat berpengaruh pada berbagai organ ikan dan tingkat kerusakan yang timbul pada organ tersebut tergantung pada konsentrasi pencemaran dan waktu pemaparan. Beberapa organ ikan yang secara nyata dapat mengalami degradasi fungsi dengan adanya pencemaran detergen dalam air antara lain kulit, insang, organ pencernaan dan bahkan hati ikan. Hasil penelitian Supriyono et al. (2008) bahwa surfaktan pada konsentrasi akut dapat menyebabkan kematian dan perubahan tingkah laku serta kerusakan organ insang dan hepatopankreas pada post larva udang Windu, sedangkan konsentrasi sub kronis secara nyata menyebabkan turunnya laju pertumbuhan, menyebabkan perubahan tingkah laku, dan kerusakan struktur insang dan hepatopankreas juvenil udang windu. Kemudian hasil penelitian Ambariyanto (2011) menemukan bahwa surfaktan (dalam bentuk sabun komersial) secara signifikan bersifat toksik terhadap zooxanthellae, dapat memberikan pengaruh terhadap penurunan jumlah semua zooxanthellae yang diisolasi dari ketiga jenis karang (Acropora aspera, Porites lutea, dan Montipora digitata) secara drastis dalam waktu yang sangat singkat dan bisa berdampak sampai pada kematian massal zooxanthellae.

\section{Konsentrasi Minyak di Perairan Depapre}

Sebagai wilayah yang memiliki perairan laut yang cukup luas, masyarakat yang bermukim di wilayah pesisir serta memanfaatkan laut sebagai sumber mata pencaharian dan sarana transportasi, perairan laut Distrik depapre tentunya tidak akan terlepas dari dampak pencemaran minyak di perairan laut. Hasil analisis menunjukkan bahwa konsentrasi minyak di perairan Distrik Depapre berkisar 0,14-0,41 mg/L (Gambar 3). Konsetrasi kandungan minyak di setiap stasiun pengamatan masih berada di bawah ambang batas maksimum konsentrasi minyak di perairan laut untuk kelangsungan hidup biota laut sebagaimana dalam KEPMEN Negara Lingkungan Hidup No. 51 tahun 2004, yaitu 1 $\mathrm{mg} / \mathrm{L}$.

Berdasarkan hasil yang diperoleh tersebut, perairan laut Distrik Depapre saat ini tergolong belum tercemar oleh bahan pencemar minyak (hidrokarbon), termasuk lemak dan masih aman untuk berbagai biota laut. Beberapa sumber limbah berminyak yang teridentifikasi di perairan Distrik Depapre berasal dari kegiatan domestik (rumah tangga) yang kebanyakan terbuang ke laut dan sungai, buangan bahan bakar perahu masyarakat (sebagai sarana transportasi dan untuk kegiatan perikanan) dan pembuangan air balance perahu dan kapal masyarakat, serta bahan bakar kapal berukuran besar yang melintasi perairan Kabupaten Jayapura. Konsentrasi kandungan minyak di perairan Distrik Depapre diprediksi akan terus bertambah seiring dengan bertambahnya jumlah penduduk dan sarana transportasi laut masyarakat setempat yang memanfaatkan minyak sebagai bahan bakarnya. Hal ini dapat terjadi karena sebagian besar mata pencaharian masyarakat Distrik Depapre sebagai nelayan dan juga transportasi laut merupakan transportasi utama. Kondisi ini apabila 


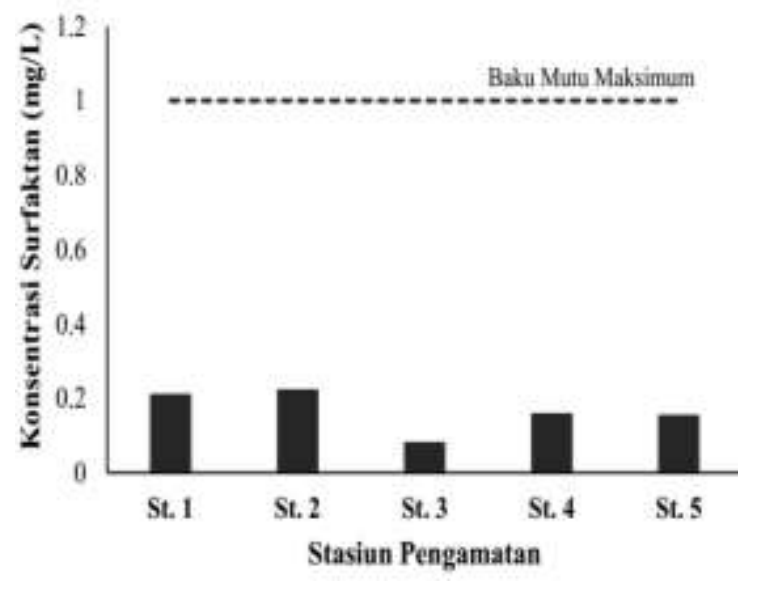

Gambar 2. Konsentrasi surfaktan di perairan Distrik Depapre, Kabupaten Jayapura

berlangsung secara terus-menerus dalam waktu yang lama, maka akan menyebabkan terjadinya pencemaran di perairan laut dan secara tidak langsung akan berpengaruh terhadap biota laut.

Perairan laut sering terkena tumpahan minyak sebagai akibat dari transportasi laut, pengeboran minyak atau penggunaan bahan bakar (Brussaard et al., 2016). Pencemaran minyak di perairan laut dapat menimbulkan dampak yang merugikan, baik secara ekologis, ekonomi, dan dapat berdampak bagi kesehatan manusia (Darmayati, 2013; Wang et al., 2014; Li et al., 2018). Dampak terhadap organisme laut antara lain mengganggu proses reproduksi, pengembangan ekosistem, pertumbuhan, dan perilaku biota laut (Yamamoto et al., 2003). Pencemaran minyak dapat berdampak langsung terhadap kematian organis melaut (Sulistyono, 2013).Resiko kematian masal akan lebih besar lagi bagi ikan-ikan di tambak ataupun di keramba serta jenis kerang-kerangan yang kemampuan migrasi yang sangat rendah untuk menghindari tumpahan minyak (Davis et al., 1984).

Tumpahan minyak yang menutupi permukaan air akan menurunkan DO dan menaikkan COD dan BOD serta daya hantar listrik. Kondisi tersebut dapat mempengaruhi proses adaptasi mangrove Soneratia caseolaris dan udang Macrobrachium rosenbergii dengan mengeluarkan isoenzim Esterase (Setyono dan Soetarto, 2008). Akibat jangka pendek dari pencemaran minyak antara lain adalah bahwa molekul-molekul hidrokarbon minyak dapat merusak membran sel biota laut, mengakibatkan keluarnya cairan sel dan berpenetrasinya bahan tersebut ke dalam sel (Kuncowati, 2010). Secara langsung minyak akan menyebabkan kematian pada ikan disebabkan kekurangan oksigen,

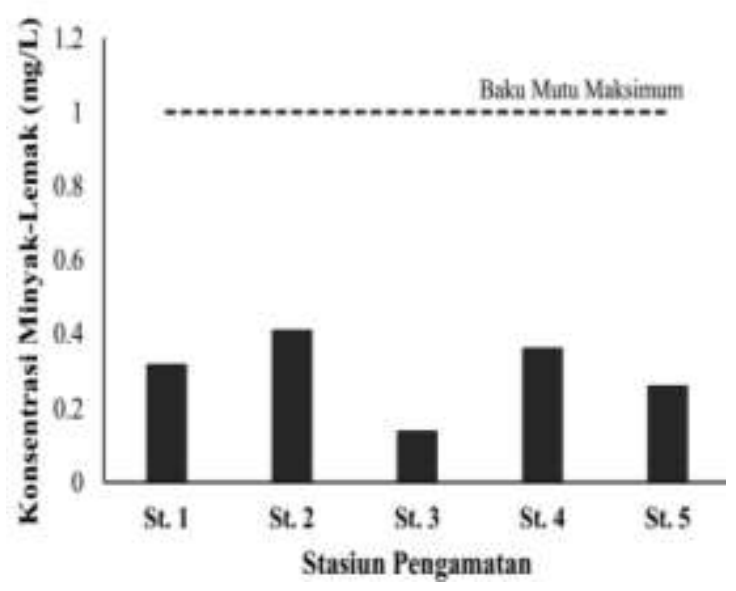

Gambar 3.Konsentrasi minyak-lemak di perairan Distrik Depapre, Kabupaten Jayapura

keracunan karbondioksida, dan keracunan langsung oleh bahan berbahaya. Sedangkan akibat jangka panjang dari pencemaran minyak adalah terutama bagi biota laut yang masih muda. Minyak di dalam laut dapat termakan oleh biotabiota laut. Sebagian senyawa minyak dapat dikeluarkan bersama-sama makanan dan sebagian lagi dapat terakumulasi dalam senyawa lemak dan protein. Sifat akumulasi ini dapat dipindahkan dari organisme satu ke organisme lain melalui rantai makanan.

\section{KESIMPULAN}

Konsentrasi surfaktan dan minyak pada semua stasiun penelitian masih di bawah nilai ambang batas maksimum. Sebagian besar sumber pencemaran surfaktan dan minyak berasal dari aktifikas masyarakat, melalui pembuangan limbah domestik rumah tangga dan penggunaan sarana transportasi laut. Bahan pencemar surfaktan dan minyak telah terdeteksi di perairan Distrik Depapre walaupun belum menunjukkan tingkat pencemaran yang signifikan. Hal ini berarti bahwa perairan Depapre telah terkontaminasi senyawa surfaktan dan minyak, namun belum pada kategori tercemar. Namun, tidak menutup kemungkinan bahwa konsentrasi tersebut dapat terus meningkat, sehingga di perlukan upaya lebih lanjut dari pemerintah dan masyarakat setempat untuk meminimalkan jumlah konsentrasi limbah surfaktan dan minyak yang masuk ke perairan.

\section{DAFTAR PUSTAKA}

Ambariyanto, 2011. Pengaruh Surfaktan dan Hidrokarbon Terhadap Zooxanthellae. Ilmu Kelautan: Indonesian Journal of Marine Sciences, 16(1):30-34. 
Ariani, F., Effendi, H. \& Suprihatin., 2016. Water and Sediment Oil Content Spread in Dumai Coastal Waters, Riau Province, Indonesia. Egyptian Journal of Aquatic Research, 42:411-416.

Becker, A.M., Gerstmann, S. \& Frank, H., 2008. Perfluorooctane Surfactants in Waste Waters, the Major Source of River Pollution. Chemosphere, 72(1):115-121.

Brussaard, C.P.D. Peperzak, L., Beggah, S., Wick, L.Y., Birgit Wuerz, Weber, J.,Arey, J.S., van der Burg, B., Jonas, A., Huisman, J. \& van der Meer, J.R., 2016. Immediate Ecotoxicological Effects of Short-Lived OilSpills on Marine Biota. Nature Communications, 7:11206.

Darmayati, Y., 2013. Pengenalan Tentang Bioremediasi Untuk Perairan Pantai Tercemar Minyak. Oseana, 38(2):69-78.

Davis, W.P., Hoss, D.E., Scott, G.I. \& Sheridan, P.F., 1984. Fisheries Resource Impacts from Spills of Oil or Hazardous Substances, Cairns, J. \&Buikema, A.L. (ed.): Restoration of Habitats Impacted by Oil Spills, ButterworthHeinemann, Oxford.

Gholizadeh, M.H., Melesse, A.M. \&Reddi, L., 2016. A Comprehensive Review on Water Quality Parameters Estimation Using Remote Sensing Techniques. Sensors, 16(8):e1298.

Hamuna, B., Tanjung, R.H.R., Suwito, Maury, H.K. \&Alianto., 2018. Kajian Kualitas Air Lautdan Indeks Pencemaran Berdasarkan Parameter Fisika-Kimia Di Perairan Distrik Depapre, Jayapura. Jurnal Ilmu Lingkungan, 16(1):35-43.

Kementerian Negara Lingkungan Hidup., 2004. Keputusan Menteri Negara Lingkungan Hidup Nomor 51 Tahun 2004 Tentang Baku Mutu Air Laut. Jakarta.

Kuncowati, 2010. Pengaruh Pencemaran Minyak di Laut Terhadap Ekosistem Laut. Jurnal Aplikasi Pelayaran dan Kepelabuhanan, 1(1):18-22.

Li, F., Dong, H. \& Liang, M., 2018. Analysis, Treatment and Countermeasures on Oil Spills at Sea. IOP Conf. Series: Materials Science and Engineering, 397:012086.

Pemerintah Republik Indonesia., 1999. Peraturan Pemerintah Republik Indonesia Nomor 19 Tahun 1999 Tentang Pengendalian Pencemaran dan/atau Pengrusakan Laut. Jakarta.

Perez, C., Velando, A., Munilla, I., Lopez-Alonzo, M. \& Oro, D., 2008. Monitoring Polycyclic Aromatic Hydrocarbon Pollution in the Marine
Environment after the Prestige Oil Spill by Means of Seabird Blood Analysis. Environmental Science and Technology, 42(3):707-713.

Pramudyanto, B., 2014. Pengendalian Pencemaran dan Kerusakan di Wilayah Pesisir. Jurnal Lingkar Wisyaiswara, 1(4):21-40.

Rejomon, G., Balachandran, K.K., Nair, M. \& Joseph, T., 2008. Trace Metal Concentrations in Marine Zooplankton from the Western Bay of Bengal. Applied Ecology and Environmental Research, 6(1):107-116.

Riza, F., Bambang, A.N. \&Kismartini, 2015. Tingkat Pencemaran Lingkungan Perairan Ditinjau Dari Aspek Fisika, Kimia dan Logam di Pantai Kartini Jepara. Indonesian Journal of Conservation, 4(1):52-60.

Setyono, P. \& Soetarto, E.S., 2008. Biomonitoring Degradasi Ekosistem Akibat Limbah CPO di Muara Sungai Mentaya Kalimantan Tengah dengan Metode Elektromorf Isozim Esterase. Biodiversitas, 9(3):232-236.

Shaheen, E.I., 1992. Technology of Environmental Pollution Control, $2^{\text {nd }}$ ed., PennWell Books, Tulsa.

Sulistyono, 2013. Dampak Tumpahan Minyak(Oil Spill) Di Perairan Laut Pada Kegiatan Industri Migas dan Metode Penanggulangannya. Forum Teknologi, 3(1):49-57.

Supriyono, E., Berlianti, \& Nirmala, K., 2008. Studi Mengenai Toksisitas Surfaktan Deterjen, Alkyl Sulfate (As), Terhadap Post Larva Udang Windu Penaeus monodon Fabr. Jurnal Ilmu-Ilmu Perairan dan Perikanan Indonesia, 15(2):141-148.

Tanjung, R.H.R., Hamuna, B \& Alianto, 2019. Assessment of Water Quality and Pollution Index in Coastal Waters of Mimika, Indonesia. Journal of Ecological Engineering, 20(2):8794.

Taufik, I., 2006. Pencemaran Deterjen Dalam Perairan dan Dampaknya Terhadap Organisme Air. Media Akuakultur, 1(1):25-32.

Wang, H., Xu, J., Zhao, W. \& Zhang, J., 2014. Effects and Risk Evaluation of Oil Spillage in the Sea Areas of Changxing Island. International Journal of Environmental Research and Public Health, 11:8491-8507.

Yamamoto, T., Nakaoka, M., Komatsu, T. \& Kawai, H., 2003. Impacts by Heavy-Oil Spill from the Russian Tanker Nakhodka on Intertidal Ecosystems: Recovery of Animal Community. Marine Pollution Bulletin, 47(16):91-98. 